\title{
Penggunaan Berbagai Konsentrasi Kulit Buah Pepaya dalam Penurunan Kadar Kafein pada Kopi
}

\author{
The Use of Various Concentrations of Papaya Fruit Skin in Reducing Caffeine Levels in Coffee
}

\author{
S.Rosalinda1*, Tio Febriananda ${ }^{1}$, Sarifah Nurjanah ${ }^{1}$
}

\begin{abstract}
${ }^{1}$ Departemen Teknik Pertanian dan Biosistem, Fakultas Teknologi Industri Pertanian, Universitas Padjadjaran JI. Raya Bandung-Sumedang KM 21, Jatinangor, 40600, Indonesia

*E-mail: s.rosalinda@unpad.ac.id
\end{abstract}

Diterima: 10 Februari 2021; Disetujui: 4 Agustus 2021

\begin{abstract}
ABSTRAK
Biji kopi merupakan bijian penghasil minuman. Beberapa peneliti terdahulu menunjukkan bahwa kopi memiliki potensi sebagai zat antioksidan, merangsang kinerja otak dan antikanker. Kopi juga memiliki kekurangan yaitu mengandung kadar kafein yang tinggi, sehingga dapat menyebabkan beberapa efek negatif pada tubuh, seperti meningkatnya denyut jantung. Pengurangan kadar kafein dapat dilakukan dengan cara melakukan dekafeinasi pada biji kopi. Penelitian ini bertujuan untuk mengetahui pengaruh penggunaan kulit buah pepaya dalam penurunan kadar kafein kopi arabika. Penelitian ini menggunakan konsentrasi kulit papaya yang dihaluskan $(0 \%, 20 \%, 40 \%, 60 \%$, dan $80 \%)$ dengan lama waktu fermentasi selama 36 jam. Hasil perlakuan dibandingkan dengan data kontrol (kopi standar produksi Poktan Kopi Manglayang) sebagai acuan penelitian. Kopi bubuk yang dihasilkan telah dilakukan analisa kadar kafein, kadar air, kadar abu, dan uji hedonik. Hasil analisa menunjukkan bahwa nilai perlakuan terbaik terdapat pada konsentrasi kulit pepaya $80 \%$. Perlakuan terbaik ini menghasilkan kadar air $3,48 \% \pm$ 0,01 , kadar kafein $1,07 \% \pm 0,06$, kadar abu 3,46\% $\pm 0,02$, dan uji hedonik dengan nilai analisa warna 4,17; analisa aroma 3,7; analisa rasa 3 dan 3,43 dan analisa aftertaste 3,43 . Hasil analisa kadar kafein didapatkan bahwa konsentrasi $0 \%$ sebesar $1,40 \% \pm 0,02$, konsentrasi $20 \%$ sebesar $1,38 \% \pm 0,02$, konsentrasi $40 \%$ sebesar $1,24 \% \pm 0,04$, konsentrasi $60 \%$ sebesar $1,13 \% \pm 0,08$. Kesimpulan dari penelitian menunjukkan bahwa enzim papain yang terdapat pada kulit buah pepaya mampu menurunkan kadar kafein.
\end{abstract}

Kata kunci: dekafeinasi; kopi arabika; kulit papaya; penurunan kafein

\begin{abstract}
Coffee (Coffea sp) is a beverage-producing grain. Several previous researchers have shown that coffee also has the potential as an antioxidant, stimulating brain performance and as an anticancer agent. Coffee also has the disadvantage that it contains high levels of caffeine, so it can cause some negative effects on the body, such as increased heart rate. Reducing caffeine levels can be done by decaffeinating coffee beans. This study aims to determine the effect of using papaya peel in decreasing the caffeine content of Arabica coffee. This study used papaya peel concentrations (0\%, 20\%, 40\%, 60\%, and $80 \%$ ) with a fermentation time of 36 hours. The results of the treatment were compared with control data (standard coffee produced by Poktan Kopi Manglayang) as a research reference. The resulting ground coffee has been analyzed for caffeine content, moisture content, ash content, and organoleptic tests. The results of the analysis showed that the best treatment value was found in the $80 \%$ papaya peel concentration. This treatment resulted in a caffeine content of $1.11 \% \pm 0.06$, a moisture content of $3.47 \% \pm 0.01$, an ash content of $3.48 \% \pm 0.02$, and an organoleptic test with a value of 4.17 (color), 3, 7 (aroma), 3 (taste), and 3.43 (aftertaste) on a scale of 1-5. The results of the analysis of caffeine levels showed that the concentration of $0 \%$ was $1.38 \% \pm 0.02$, the concentration of $20 \%$ was $1.37 \% \pm 0.02$, the concentration of $40 \%$ was $1.27 \% \pm 0.04$, $60 \%$ concentration was $1,19 \% \pm 0.08$, and an $80 \%$ concentration of $1.12 \% \pm 0.06$ indicated that the papain enzyme contained in papaya peel was able to reduce caffeine levels.
\end{abstract}

Keywords: arabica coffee; caffeine reduction; decaffeination; papaya peel

\section{PENDAHULUAN}

Kopi (Coffea sp) merupakan salah satu bijian penghasil minuman yang sudah sangat dikenal dikalangan masyarakat (Anggara \& Marini, 2011). Kopi disukai karena mempunyai cita rasa dan aroma yang khas. Menurut Rejo dkk (2010), kopi bermanfaat sebagai zat antioksidan bagi tubuh, merangsang kinerja otak, dan antikanker. Kandungan antioksidan kopi lebih banyak dibandingkan antioksidan pada teh dan cokelat (Ramalakshmi dkk., 2008). Kopi selain mempunyai kelebihan, juga memiliki kekurangan yaitu mengandung kafein yang tinggi. Kadar kafein yang tinggi dapat menyebabkan beberapa gangguan kesehatan, seperti insomnia, kegelisahan, iritasi pada perut, mual dan muntah, peningkatan detak jantung dan respirasi, tekanan darah tinggi, kesulitan tidur, kecemasan, dan kehilangan nafsu makan. Kandungan kadar kafein pada biji kopi berbeda-beda tergantung pada jenis kopi dan kondisi geografis tempat kopi tersebut ditanam (Farida dkk., 2013).

Kopi arabika (Coffea arabica) adalah kopi yang paling baik mutu cita rasanya dibanding jenis kopi yang lain. Budidaya dan pengolahan kopi arabika dan robusta saat ini banyak diminati masyarakat (Rahardjo, 2012). Kopi arabika memang dikenal terlebih dahulu oleh konsumen di banyak negara, sehingga kelezatan kopi arabika lebih dikenal superior dibandingkan dengan kopi robusta (Israyanti, 2021). 
Jenis-jenis kopi yang termasuk dalam golongan arabika adalah abesinia, pasumah, marago dan congensis.

Menurut data Direktorat Jenderal Perkebunan tahun 2016, Jawa Barat menempati urutan ke 11 terbesar produsen kopi nasional. Luas lahan tanaman kopi di Jawa Barat mencapai 32.538 ha dan menghasilkan 16.645 ton kopi. Pemerintahan daerah Jawa Barat berupaya mengembangkan kopi khas Jawa barat dan berhasil mendapatkan indikasi geografis pada tahun 2013. Desa di Jawa Barat mempunyai potensi yang besar untuk pengembangan komoditas kopi arabika yang saat ini sudah dibudidayakan salah satunya di kawasan Gunung Manglayang, Kecamatan Ujung Berung. Kopi arabika ini merupakan tanaman kopi yang paling banyak ditanam di Jawa Barat.

Menurut Petracco (2005), kandungan kafein kopi Arabika sebesar $0,4-2,4 \%$ dari total berat kering sedangkan kopi Robusta mengandung kafein $1-2$. Kopi Arabika memiliki pH sekitar 4,85-5,15. Kafein merupakan zat antagonis reseptor adenosin sentral yang dapat mengganggu fungsi sistem saraf pusat dan memiliki efek gangguan pada saat tidur. Anak yang mengkonsumsi minuman berkafein sedikitnya sekali sehari, mempunyai jumlah waktu tidur 3 jam 30 menit (dalam satu minggu) kurang berbanding anak yang tidak mengkonsumsi minuman berkafein (Kirchheimer \& Smith, 2004). Liska (2004), menyatakan bahwa kadar kafein yang diizinkan ialah 100-200 mg/hari, sedangkan menurut BSN (2004) SNI 01-7152-2006 mengenai batas maksimum kadar kafein dalam industri pangan adalah $150 \mathrm{mg} / \mathrm{hari}$ dan 50 $\mathrm{mg} / \mathrm{sajian}$. Kafein dapat menyebabkan beberapa efek negatif jangka pendek pada tubuh seperti meningkatnya denyut jantung, peningkatan respirasi, kecepatan metabolisme basal, refleks gastrointestinal, dan produksi asam lambung serta urin yang berlebih, sehingga setelah meminum kopi seseorang cenderung lebih sering buang air. Lamanya efek dari produk pangan berkafein tergantung oleh status hormonal seseorang, kebiasaan merokok, sedang menjalani pengobatan atau memiliki penyakit yang merusak fungsi hati (Erowid, 2014).

Salah satu cara untuk mengatasi dampak dari efek kafein berlebih dalam mengonsumsi kopi yaitu dengan cara melakukan dekafeinasi pada biji kopi. Dekafeinasi ialah proses penurunan kadar kafein atau bahkan penghilangan kadar kafein pada suatu produk pangan, baik secara alami maupun dengan menggunakan bahan kimia. Kafein yang ada pada kopi berada di membran sel, dimana membran sel memiliki kandungan $40 \%$ lemak, $52 \%$ protein, dan $8 \%$ karbohidrat (Yatim, 2003). Komponen terbesar dalam membran sel adalah protein. Menurunkan kadar kafein dalam biji kopi dibutuhkan pemecahan komponen yang ada dalam membran. Protein dapat dihidrolisis oleh suatu enzim pemecah protein yang disebut enzim proteolitik. Enzim proteolitik dapat membantu melunakkan serta memecahkan komponen dalam membran sel sehingga memudahkan proses pelarutan kafein. Enzim proteolitik memiliki beberapa jenis seperti enzim papain dari pepaya, bromelin dari nanas, rennin dari sapi dan babi, serta fisin dari getah pohon ficus yang mempunyai sifat menghidrolisis protein (Nazar dkk., 2016). Penelitian yang dilakukan oleh Kristiyanto dkk (2013) melakukan fermentasi dalam penurunan kadar kafein menggunakan Napkor MZ-15, Oktadina dkk (2013) melakukan dekafeinasi melalui proses fermentasi menggunakan buah nanas dimana kadar kafein menurun dari $2,27 \%$ menjadi $1,15 \%$ dengan lama fermentasi terbaik yaitu 36 jam. Hasil ini membuktikan bahwa enzim bromelin yang ada pada nanas mampu menurunkan kadar kafein. Putri \& Komang (2017) melakukan dekafeinasi melalui proses fermentasi selama 2 jam menggunakan buah pepaya, dimana kadar kafein menurun dari 1,53\% menjadi $0,24 \%$ dengan konsentrasi getah pepaya terbaik sebanyak $6 \%$. Hasil ini menandakan bahwa enzim papain yang terdapat pada pepaya mampu menurunkan kadar kafein. Menurut Nuryati dkk (2018) kandungan enzim papain di dalam buah pepaya dari $100 \mathrm{~g}$ masing-masing bahan, didapatkan kandungannya sebesar 78,79 g pada biji, 120,86 g pada daun, dan $125,88 \mathrm{~g}$ pada kulit buah pepaya. Enzim papain yang akan digunakan pada penelitian ini didapatkan dari kulit buah pepaya.

Berdasarkan literatur diatas, penelitian ini melakukan pemanfaatan kulit buah pepaya dalam mengurangi kadar kafein pada kopi arabika. Pemilihan kopi jenis arabika juga berdasarkan keberlanjutan dari praktek kerja lapang yang telah dilakukan di Poktan Kopi Manglayang, yang menggunakan jenis kopi arabika dan fermentasi dilakukan secara fullwash.

\section{METODOLOGI}

Bahan baku utama yang digunakan pada penelitian ini adalah ceri kopi berwarna merah sempurna yang berasal dari Poktan Kopi Manglayang (Desa Cipanjalu, Kecamatan Cilengkrang, Bandung, Jawa Barat). Bahan yang digunakan adalah kulit buah pepaya california (carica papaya L.) dari pasar lokal yang berumur 2,5-3 bulan. Alat yang digunakan adalah: Mesin Pulping, Mesin Huling, Mesin Roasting, Mesin Pengecil Ukuran Kopi (Grinding), Oven, Tanur, Desikator, Moisture Meter dan bahan kimia: Magnesium Oksida, asam sulfat $\left(\mathrm{H}_{2} \mathrm{SO}_{4}\right)$, kalium hidroksida $(\mathrm{KOH})$, kloroform $\left(\mathrm{CHCl}_{3}\right)$, kertas saring, dan akuades.

Pada penelitian ini, pembuatan bubuk kopi dimulai dari buah ceri yang baru dipetik, selanjutnya ceri akan dilakukan proses sortasi untuk memilih ceri yang berwarna merah sempurna. Kemudian ceri akan melalui proses rambangan, yaitu proses perendaman ceri dalam air bersih dengan tujuan untuk memisahkan ceri yang bagus (tenggelam) dan ceri yang tidak bagus (mengapung). Ceri tersebut selanjutnya akan dilakukan proses pulping, yaitu proses pemisahan biji kopi dengan daging buah ceri. Biji kopi yang telah terlepas dari daging buah, selanjutnya akan disimpan dalam karung beras dengan berat $\pm 2 \mathrm{~kg}$ untuk masing masing konsentrasi $20 \%$, 40\%, 60\%, dan $80 \%$ dan akan dilakukan fermentasi selama 36 jam. Pembuatan kopi pada penelitian ini dilakukan secara fullwash. Tahapan penelitian dapat dilihat pada Gambar 1.

Metode yang digunakan pada penelitian adalah metode eksperimental laboratorium dengan analisis deskriptif. Penelitian dilakukan dengan konsentrasi kulit buah pepaya $(0 \%, 20 \%, 40 \%, 60 \%$, dan $80 \%)$ dan waktu fermentasi $(36$ jam). Kulit buah pepaya $20 \%$ adalah penimbangan kulit pepaya sebanyak 20 gram kemudian ditambahkan air hingga $100 \mathrm{ml}$ selanjutnya dihaluskan hingga berbentuk bubur dengan konsistensi waktu dan kecepatan penghalusan. Dilakukan perlakuan yang sama pada masing masing konsentrasi. Parameter yang dianalisis untuk mutu kopi dari hasil penelitian adalah: Uji kadar kafein (SNI 01-3542-2004) untuk mengetahui penurunan kadar kafein yang terjadi setelah penambahan konsentrasi kulit buah pepaya. Uji hedonik (cita rasa dan aroma), dimana atribut dari uji hedonik berasal dari 30 panelis. Uji kadar air (SNI 01-2907-2008) dan kadar abu (SNI 01-3542-2004) juga dilakukan untuk mengetahui perubahan yang terjadi dengan penambahan konsentrasi kulit buah pepaya. Kopi hasil penelitian juga akan dibandingkan hasilnya dengan standar SNI 01-35422004. 


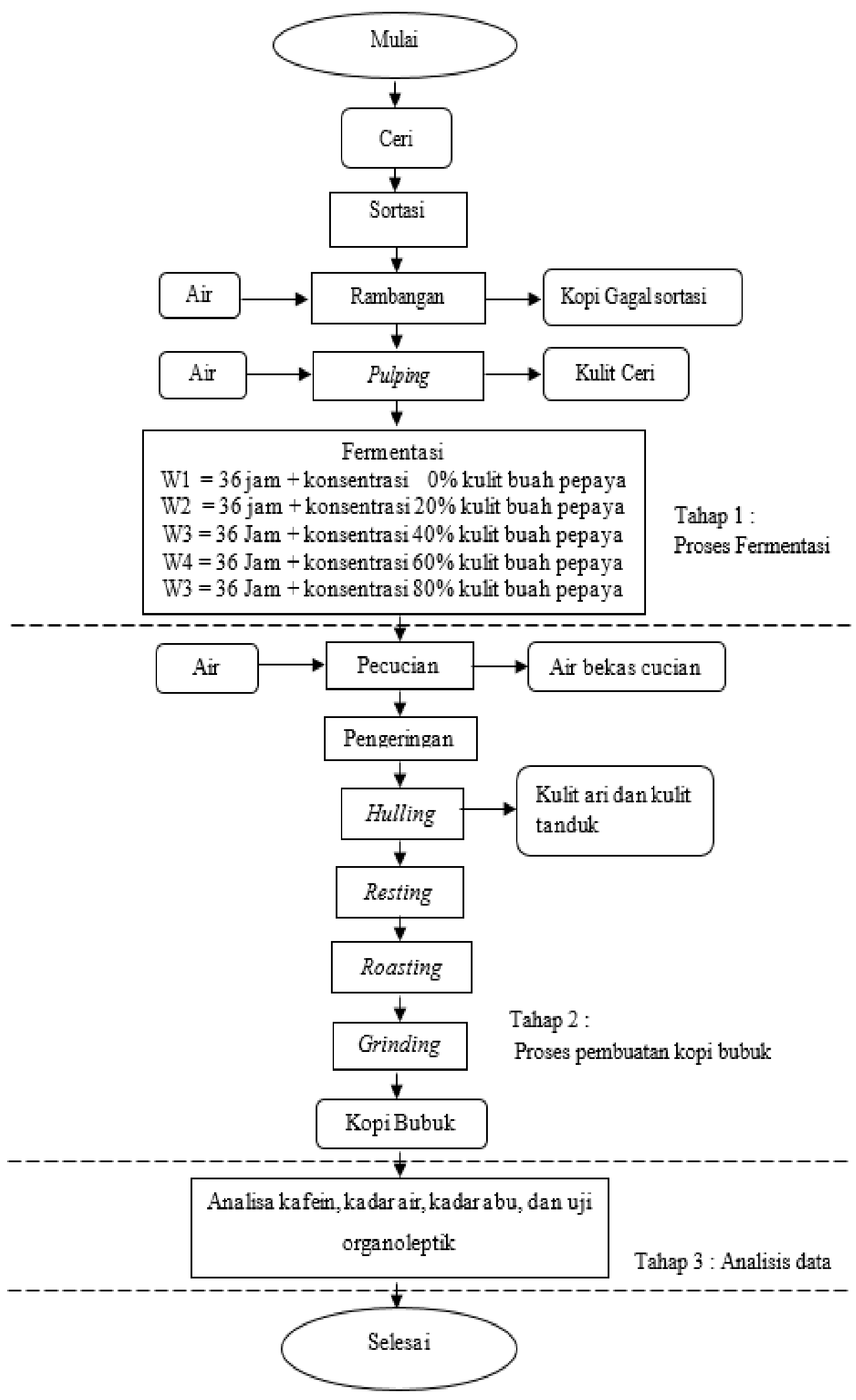

Gambar 1. Tahapan penelitian 


\section{HASIL DAN PEMBAHASAN}

\section{Kadar Air Biji Kopi}

Hasil analisis kadar air biji kopi arabika pada berbagai konsentrasi kulit buah pepaya yang telah difermentasi selama 36 jam dapat dilihat pada Gambar 2. Gambar 2 menunjukkan hasil dari pengukuran antara kadar air dan konsentrasi kulit papaya. Penambahan berbagai konsentrasi kulit buah pepaya menunjukan kecenderungan meningkatnya kandungan kadar air bubuk kopi dari konsentrasi $0 \%$ hingga $60 \%$, kemudian mengalami penurunan pada konsentrasi $80 \%$. Pada konsentrasi $0 \%$ memiliki kandungan kadar air yang paling rendah dengan nilai $2,46 \% \pm 0,01$ sedangkan pada konsentrasi $60 \%$ merupakan konsentrasi yang memiliki kadar air paling tinggi dengan nilai 4,93\% $\pm 0,09$; sementara pada konsentrasi $20 \%$ memiliki kadar air sebesar 3,98\% $\pm 0,06$; pada konsentrasi $40 \%$ memiliki kadar air sebesar $3,94 \% \pm 0,32$; dan pada konsentrasi $80 \%$ memiliki kadar air sebesar 3,48\% $\pm 0,01$. Kandungan kadar air pada penelitian ini masih dalam batas normal, karena kadar air tersebut masih dibawah batas maksimal dari SNI 01-3542-2004 dengan kadar air maksimum $7 \%$. Penurunan kadar air pada konsentrasi $80 \%$ disebabkan larutan menjadi kental sehingga gerakan molekul air menjadi lambat.

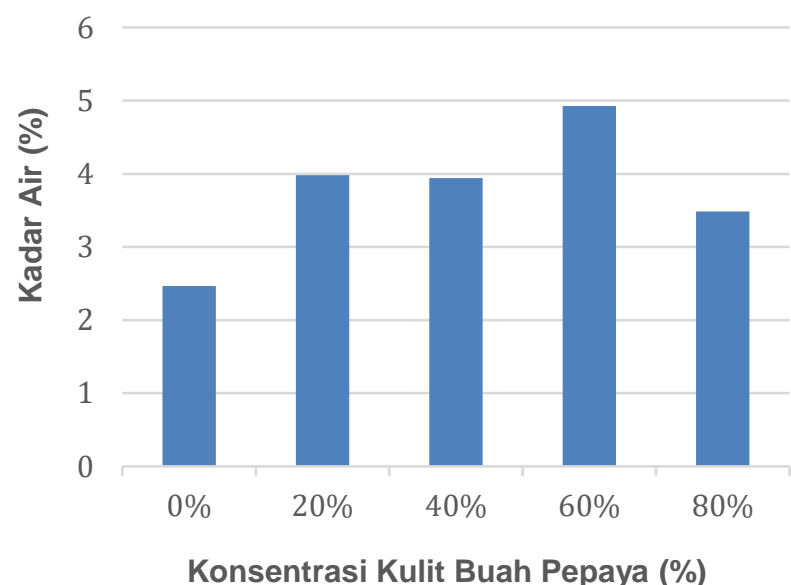

Gambar 2. Kadar air berbagai konsentrasi kulit buah pepaya

Proses perendaman dengan konsentrasi kulit buah pepaya akan memecah komponen protein yang ada pada dinding sel sehingga pori-pori jaringan biji kopi menjadi terbuka dan dimanfaatkan oleh air molekul pelarut yang bergerak cepat masuk kedalamnya. Molekul air masuk ke dalam biji kopi dengan cara difusi kemudian menembus dinding sel di dalam jaringan biji menyebabkan molekul air terperangkap di dalam sel (Mulato dkk., 2004). Dalam proses pengolahan, biji kopi kehilangan air paling banyak terjadi pada proses pengeringan dan proses penyangraian. Air yang ada di dalam biji kopi, semula memiiki sifat terikat secara kimia. Proses fermentasi membuat air yang terikat akan menjadi air bebas yang terdapat pada permukaan biji kopi. Pada saat dilakukan pengeringan biji kopi dari hasil fermentasi, maka air bebas tersebut akan menguap. Menurut Hawa dkk (2009) proses penguapan air dari bahan meliputi lima tahap, yaitu (1) pelepasan ikatan air dari bahan, (2) difusi air dan uap air ke permukaan bahan, (3) perubahan fase menjadi uap air, (4) transfer uap air dari permukaan bahan ke udara sekitarnya dan (5) perpindahan uap air di udara.

\section{Kadar Abu Biji Kopi}

Hasil analisis kadar abu biji kopi arabika pada berbagai konsentrasi kulit buah pepaya yang telah difermentasi selama 36 jam dapat dilihat pada Gambar 3. Hasil pengukuran menunjukkan pada konsentrasi $60 \%$ memiliki kandungan kadar abu yang paling tinggi dengan nilai 4,95\% $\pm 0,04$; sedangkan pada konsentrasi $80 \%$ merupakan konsentrasi yang memiliki kadar abu paling rendah dengan nilai 3,46\% $\pm 0,02$; sementara pada konsentrasi $0 \%$ memiliki kadar abu sebesar 3,98\% $\pm 0,34$; pada konsentrasi sampel $20 \%$ memiliki kadar abu sebesar $3,48 \% \pm 0,07$ dan pada konsentrasi sampel $40 \%$ memiliki kadar abu sebesar 3,5\% \pm 0,03 ; hal ini dapat dijelaskan pada tahapan proses perendaman dan pencucian.

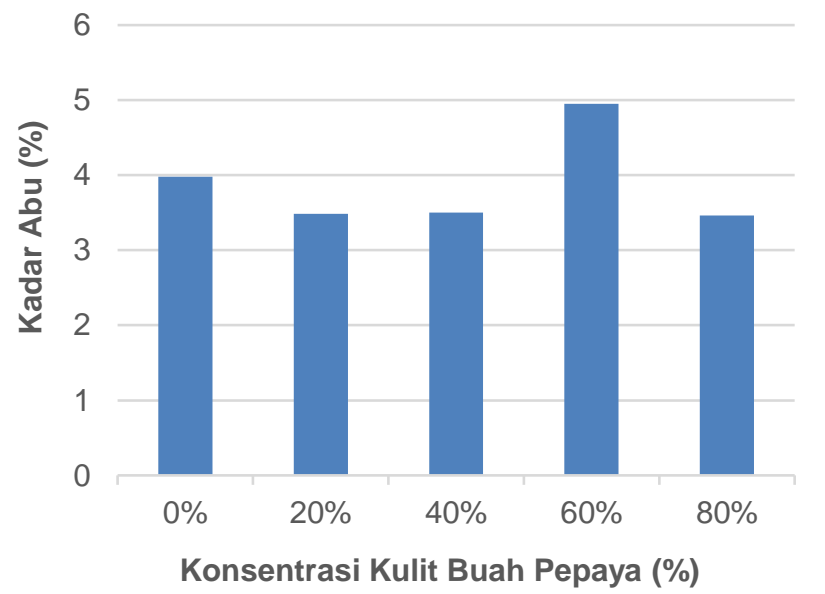

Gambar 3. Kadar abu berbagai konsentrasi kulit buah pepaya

Proses perendaman biji kopi dengan kulit buah pepaya akan merusak dinding sel yang nantinya komponen mineral larut dalam air seperti kalsium, magnesium, natrium, kalium, klor, bikarbonat dan sulfat akan keluar dari sel dan menyebabkan kadar mineral akan menurun. Proses pencucian setelah perendaman mengakibatkan kadar abu pada biji menurun. Air pencucian akan membilas sisa-sisa mineral yang larut dan dibawa oleh air pencuci sehingga komponen mineral yang tertinggal menjadi lebih sedikit. Kandungan kadar abu pada penelitian ini masih dalam batas normal, karena kadar abu tersebut masih dibawah batas maksimal dari SNI 01-3542-2004 dengan kadar abu maksimal 5\%. Kadar abu merupakan campuran dari komponen anorganik atau mineral yang terdapat pada suatu bahan pangan. Bahan-bahan organik dalam proses pembakaran akan terbakar sebaliknya komponen anorganiknya tidak. Kandungan abu juga dapat digunakan untuk memperkirakan kandungan dan kemurnian bahan yang digunakan. Kandungan abu dan komposisinya tergantung pada macam bahan dan cara pengabuannya. Kadar abu ada hubungannya dengan mineral suatu bahan. Mineral yang terdapat dalam suatu bahan dapat berasal dari garam-garam organik (misalnya asam malat, oksalat, asetat, pekat dan lain-lain) dan garam-garam anorganik (misalnya fosfat, karbonat, klorida, sulfat, nitrat dan logam alkali). Selain itu, mineral dapat terbentuk sebagai senyawa kompleks yang bersifat organik. Apabila akan ditentukan jumlah mineral dalam bentuk aslinya itu sangat sulit. Oleh karena itu biasanya dilakukan dengan menentukan sisa pembakaran garam mineral tersebut yang dikenal dengan pengabuan. 


\section{Kadar Kafein Bubuk Kopi}

Hasil analisis kadar kafein bubuk kopi arabika pada berbagai konsentrasi kulit buah pepaya yang telah difermentasi selama 36 jam dapat dilihat pada Gambar 4. Gambar 4 menunjukkan kulit buah pepaya dengan konsentrasi $40 \%$, 60\% dan $80 \%$ memberikan perbedaan terhadap kadar kafein pada kontrol $(0 \%)$, sedangkan pada konsentrasi kulit buah pepaya $20 \%$ tidak berbeda. Pada konsentrasi $0 \%$ memiliki kandungan kadar kafein yang paling tinggi dengan nilai $1,40 \% \pm 0,02$; sedangkan pada konsentrasi $80 \%$ merupakan konsentrasi yang memiliki kadar kafein paling rendah dengan nilai $1,07 \% \pm 0,06$; sementara pada konsentrasi $20 \%$ memiliki kadar kafein sebesar 1,38\% $\pm 0,02$; pada konsentrasi $40 \%$ memiliki kadar kafein sebesar $1,24 \% \pm 0,04$ dan pada konsentrasi $60 \%$ memiliki kadar kafein sebesar $1,13 \% \pm 0,08$. Hasil dari pengukuran menunjukkan bahwa penambahan berbagai konsentrasi kulit buah pepaya menghasilkan kadar kafein yang cenderung menurun pada bubuk kopi. Menurut SNI 01 3542-2004 tentang standar mutu kopi bubuk, kadar kafein yang diizinkan adalah pada kisaran $0,9-2 \%$. Hasil penelitian ini masih memenuhi SNI 01-3542-2004.

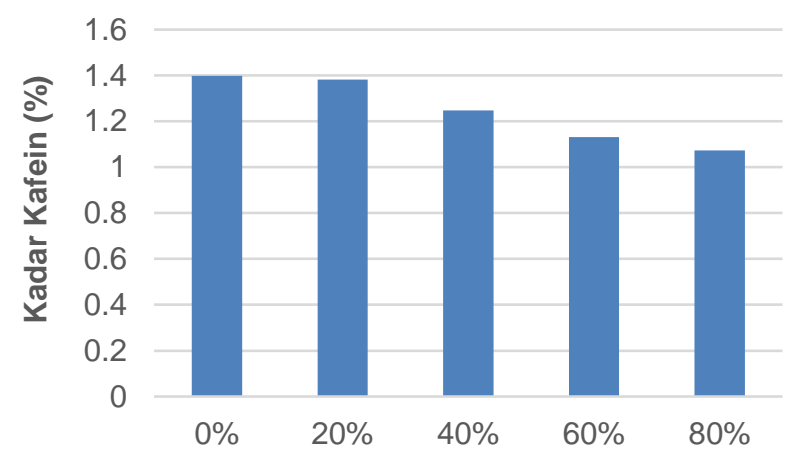

Konsentrasi Kulit Buah Pepaya (\%)

\section{Gambar 4. Kadar kafein berbagai konsentrasi kulit buah} pepaya

Kafein merupakan salah satu senyawa yang terdapat dalam biji kopi. Kafein pada biji kopi terletak pada dinding sel dan sebagian terdapat dalam sitoplasma. Kafein yang berada di dinding sel biji kopi dalam keadaan terikat dengan asam klorogenat (Farhaty \& Muchtaridi, 2016). Kafein yang terikat dengan asam klorogenat sukar larut dalam air sehingga diperlukan proses pengukusan selama 30 menit untuk memecah ikatan tersebut (Wijaya \& Yuwono, 2015). Perlakuan panas selama proses dekafeinasi mengakibatkan ikatan antara kafein dengan asam klorogenat terputus. Penggunaan berbagai konsentrasi kulit buah pepaya pada proses perendaman akan memecah protein yang ada pada dinding sel sehingga kafein yang ada pada dinding sel yang telah terputus ikatannya dengan asam klorogenat akan larut dalam air. Kadar kafein mengalami penurunan setelah proses fermentasi, hal ini dapat terjadi karena adanya perombakan kafein oleh enzim papain yang terdapat pada kulit buah pepaya. Selama proses fermentasi akan terjadi hidrolisis asam klorogenat menjadi asam kafeat secara alami, hal ini terjadi karena ikatan asam klorogenat yang semula berikatan dengan kafein terputus akibat panas selama fermentasi. Berkurangnya asam klorogenat karena hidrolisis merupakan indikasi menurunnya jumlah kafein dalam biji kopi. Pada proses penurunan kafein dengan cara fullwash prinsip fermentasi adalah peruraian senyawasenyawa yang terkandung di dalam lapisan lendir oleh mikroba alami dan dibantu dengan oksigen dari udara.
Selama proses fermentasi, akan terjadi pemecahan komponen lapisan lendir (protopektin dan gula) dengan dihasilkannya beberapa senyawa bersifat asam dan alkohol. Proses fermentasi yang terlalu lama akan menghasilkan kopi beras yang berbau apek karena terjadi pemecahan komponen pada isi lembaga (Ciptadi \& Nasution, 1985).

\section{Uji Hedonik}

Hasil analisis uji hedonik bubuk kopi arabika yang meliputi, warna, aroma, rasa dan aftertaste pada berbagai konsentrasi kulit buah pepaya yang telah difermentasi selama 36 jam dapat dilihat pada Gambar 5.

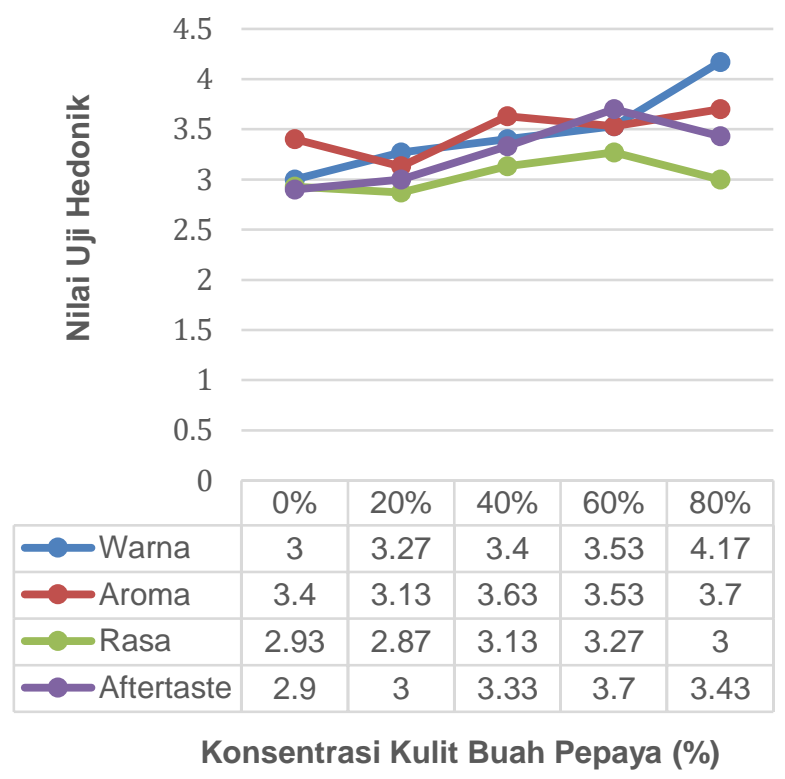

Gambar 5. Uji hedonik berbagai konsentrasi kulit buah pepaya

\section{Analisis Warna}

Warna mempunyai peranan penting pada komoditas pangan, yaitu daya tarik, tanda pengenal dan atribut mutu. Di antara sifat-sifat produk pangan, warna merupakan faktor mutu yang paling menarik perhatian konsumen dan paling cepat memberikan kesan disukai atau tidak disukai. Semakin lama waktu fermentasi akan menyebabkan pati dalam kopi terdegradasi menjadi glukosa kemudian bereaksi menjadi asam amino membentuk melanoidin yang merupakan komponen utama dalam proses pencoklatan yang terjadi pada saat penyangraian.

Warna kopi dapat mempengaruhi keputusan pada konsumen untuk menerima atau menolak suatu produk. Kopi arabika dengan penampakan yang kurang menarik tidak disukai oleh panelis, karena itu pengujian terhadap warna sangat perlu diperhatikan. Hasil penelitian menunjukkan bahwa semakin besar penambahan konsentrasi kulit buah pepaya maka semakin meningkat tingkat penerimaan. Winarno (2004) menyatakan bahwa tingkat penerimaan warna merupakan parameter pertama yang menentukan penerimaan konsumen terhadap suatu produk. Secara subjektif dengan penglihatan sangat menentukan dalam pengujian warna. Suatu bahan makanan yang bernilai gizi tinggi, enak dan teksturnya sangat baik, tidak akan dikonsumsi apabila memiliki warna yang tidak menarik. Hal ini karena membuat makanan terlihat menarik dan menjadi daya tarik utama sebelum konsumen mengenal dan menyukai sifat-sifat lainnya. 
Pada Gambar 6 hasil uji warna menunjukkan bahwa bila rerata tertinggi pada penggunaan konsentrasi $80 \%$ yaitu sebesar 4,17; sedangkan nilai terkecil pada penggunaan konsentrasi $0 \%$ yaitu 3,00. Pada konsentrasi $20 \%$ didapatkan nilai sebesar 3,27; pada konsentrasi $40 \%$ didapatkan nilai sebesar 3,40 ; dan pada konsentrasi $60 \%$ didapatkan nilai sebesar 3,53. Skor tertinggi didapatkan pada konsentrasi $80 \%$, dimana warna dari sampel kopi ini berwarna hitam pekat dan secara umum panelis menyukai kopi yang memiliki warna hitam pekat. Dari data penelitian yang telah didapatkan, peningkatan kesukaan panelis terhadap warna pada konsentrasi $80 \%$ kemungkinan disebabkan adanya interaksi kandungan kadar air, kadar abu dan kadar kafein pada konsentrasi $80 \%$ memberikan warna kopi yang disukai.

\section{WARNA}

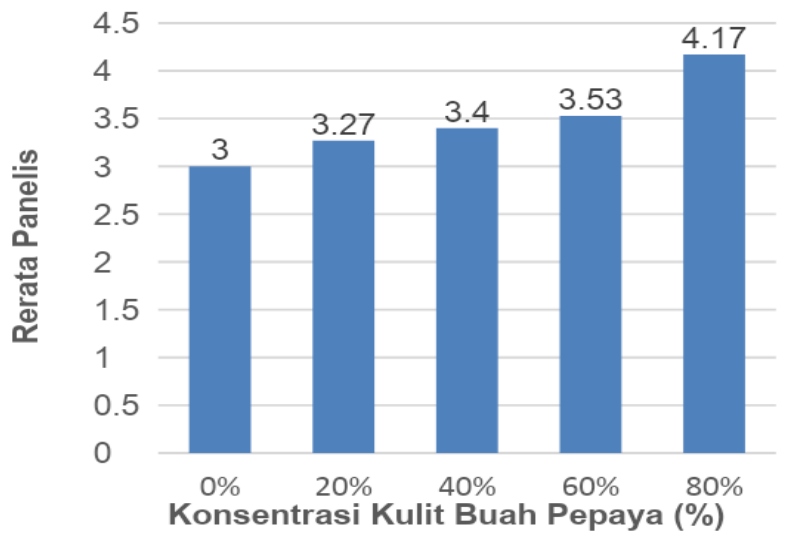

Gambar 6. Hasil uji warna berbagai konsentrasi kulit buah pepaya

\section{Analisis Rasa}

Rasa melibatkan panca indera lidah. Rasa sangat sulit dimengerti secara tuntas karena selera manusia sangat beragam. Umumnya makanan tidak hanya terdiri dari suatu kelompok rasa saja, tetapi merupakan gabungan dari berbagai rasa yang terpadu sehingga menimbulkan rasa makanan yang enak. Rasa merupakan salah satu faktor yang mempengaruhi penerimaan konsumen terhadap suatu makanan. Rasa secara umum dapat dibedakan menjadi asin, manis, pahit dan asam. Hasil uji organoleptik terhadap rasa bertujuan untuk mengetahui respon panelis mengenai kesukaan terhadap kopi yang dihasilkan pada masingmasing perlakuan penambahan konsentrasi kulit buah pepaya. Hasil uji organoleptik terhadap rasa disajikan pada Gambar 7.

Hasil uji rasa menunjukkan bahwa rasa kopi yang paling disukai oleh panelis diperoleh pada konsentrasi $40 \%$ dan $60 \%$ dengan nilai masing-masing adalah 3,13 dan 3,26; sedangkan nilai terkecil terdapat pada penggunaan konsentrasi $20 \%$ yaitu sebesar 2,87 . Pada konsentrasi $0 \%$ didapatkan nilai sebesar 2,93 dan pada konsentrasi $80 \%$ didapatkan nilai sebesar 3,00. Skor tertinggi didapatkan pada konsentrasi $40 \%$ dan $60 \%$, dimana rasa kopi ini memiliki rasa yang tidak pahit dan sedikit manis. Umumnya panelis menyukai kopi yang memiliki rasa tidak pahit. Dari data penelitian yang telah didapatkan, peningkatan kesukaan panelis terhadap rasa pada konsentrasi $40 \%$ dan $60 \%$ kemungkinan disebabkan konsentrasi fermentasi yang mempengaruhi kandungan melanoidin dalam proses pencoklatan yang terjadi pada saat penyangraian. Tahapan Proses fermentasi hingga penyangraian ini mempengaruhi rasa yang dihasilkan

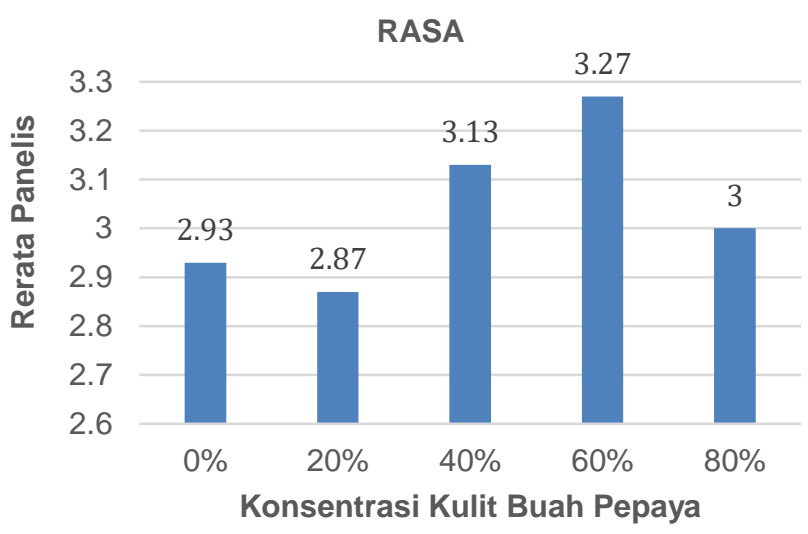

Gambar 7. Hasil uji rasa berbagai konsentrasi kulit buah pepaya

\section{Hasil Uji Aroma}

Aroma merupakan suatu nilai yang terkandung dalam produk yang langsung dapat dinikmati oleh konsumen. Aroma suatu produk dalam banyak hal menentukan bau atau tidaknya suatu produk, bahkan aroma atau bau lebih komplek dari pada rasa. Aroma kopi muncul akibat dari senyawa volatil yang tertangkap oleh indera penciuman manusia. Yusianto dkk (2012) menyatakan bahwa keasaman yang tinggi akan memberikan kualitas aroma yang lebih baik. Aroma banyak menentukan tingkat kesukaan konsumen. Aroma yang khas dan menarik dapat membuat suatu makanan lebih disukai oleh konsumen, Aroma juga merupakan salah satu faktor penting dalam menunjukkan tingkat penerimaan konsumen terhadap suatu bahan pangan. Hasil uji organoleptik aroma kopi arabika bertujuan untuk mengetahui tingkat respon dari panelis mengenai penerimaan terhadap kopi arabika pada masingmasing perlakuan. Hasil uji organoleptik aroma kopi disajikan pada Gambar 8.

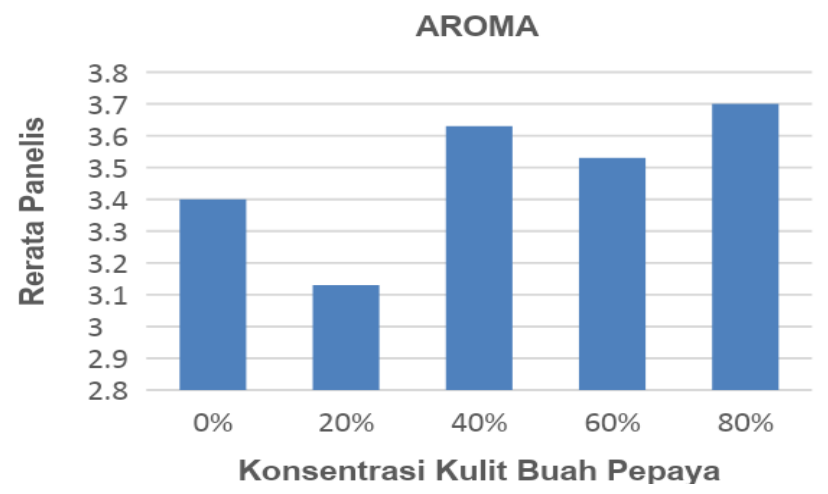

Gambar 8. Hasil uji aroma berbagai konsentrasi kulit buah papaya

Berdasarkan hasil uji organoleptik aroma pada masingmasing perlakuan dapat dilihat pada Gambar 8. Gambar 8 menunjukkan bahwa aroma yang paling disukai oleh panelis adalah pada konsentrasi $40 \%$ dan $80 \%$ dengan nilai masingmasing adalah 3,63 dan 3,70; sedangkan nilai terkecil terdapat pada penggunaan konsentrasi $20 \%$ yaitu sebesar 3,13 . Pada konsentrasi $0 \%$ didapatkan nilai sebesar 3,4 dan pada konsentrasi $60 \%$ didapatkan nilai sebesar 3,53. Pada konsentrasi $40 \%$ dan $80 \%$, dimana aroma dari sampel kopi ini sangat pekat dan secara umum panelis menyukai kopi yang memiliki aroma sangat pekat. 


\section{Hasil Uji Aftertaste}

Aftertaste merupakan rasa yang masih tertinggal ketika panelis mencoba masing-masing sampel yang ada. Aftertaste adalah rasa yang paling berpengaruh terhadap kesukaan konsumen kepada produk kopi. Hasil uji organoleptik menunjukkan bahwa nilai tertinggi terdapat pada penggunaan konsentrasi $60 \%$ yaitu sebesar 3,70; sedangkan nilai terkecil terdapat pada penggunaan konsentrasi $0 \%$ yaitu sebesar 2,90 . Pada konsentrasi $20 \%$ didapatkan nilai sebesar 3,00; pada konsentrasi $40 \%$ didapatkan nilai sebesar 3,33; dan pada konsentrasi $80 \%$ didapatkan nilai sebesar 3,43. Data penelitian yang telah didapatkan, peningkatan kesukaan panelis terhadap aftertaste pada konsentrasi $60 \%$ disebabkan adanya proses fermentasi dengan variasi konsentrasi mempengaruhi senyawa yang ada pada kopi, baik senyawa organik dan anorganik, sehingga mengurangi kadar kafein pada kopi. Data hasil aftertaste disajikan dalam Gambar 9.

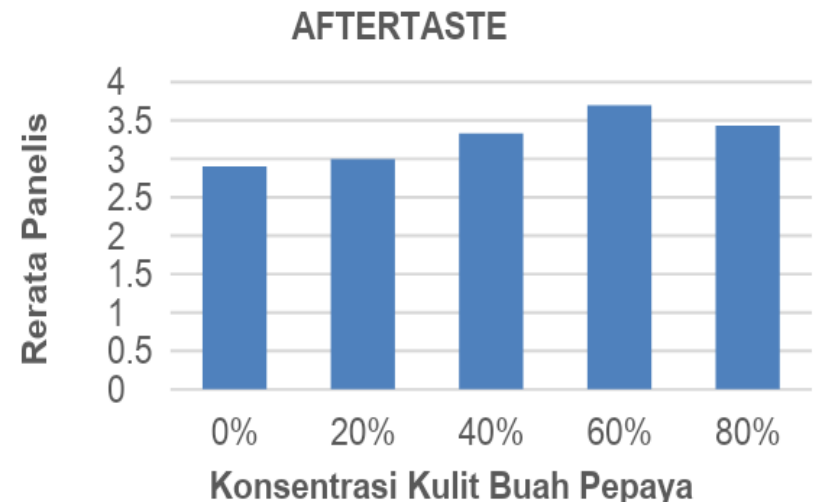

Gambar 9. Hasil uji aftertaste berbagai konsentrasi kulit buah pepaya

Uji hedonik bertujuan untuk mengetahui tingkat kesukaan panelis terhadap sampel kopi arabika yang difermentasi dan untuk memilih sampel terbaik. Uji ini dilakukan oleh 30 panelis. Dalam uji hedonik panelis diminta memberikan penilaian kesukaan kopi arabika dengan respon warna, aroma, aftertaste dan rasa. Berdasarkan hasil analisis terhadap respon maka didapatkan konsentrasi terpilih yaitu penggunaan konsentrasi $80 \%$ dari jumlah nilai total respon organoleptik dengan nilai yang terbesar.

\section{KESIMPULAN}

Hasil penelitian menunjukkan bahwa nilai perlakuan terbaik terdapat pada konsentrasi kulit pepaya $80 \%$. Perlakuan ini menghasilkan kadar kafein $1,11 \% \pm 0,06$, kadar air 3,47\% $\pm 0,01$, kadar abu 3,48\% $\pm 0,02$, dan uji hedonik dengan nilai 4,17 (warna), 3,7 (aroma), 3 (rasa), dan 3,43 (aftertaste) dari skala 1-5. Hasil analisa kadar kafein didapatkan bahwa konsentrasi $0 \%$ sebesar $1,38 \% \pm 0,02$, konsentrasi $20 \%$ sebesar $1,37 \% \pm 0,02$, konsentrasi $40 \%$ sebesar $1,27 \% \pm 0,04$, konsentrasi $60 \%$ sebesar $1,19 \% \pm$ 0,08 , dan konsentrasi $80 \%$ sebesar $1,12 \% \pm 0,06$ menunjukkan bahwa enzim papain yang terdapat pada kulit buah pepaya mampu menurunkan kadar kafein.

\section{UCAPAN TERIMAKASIH}

Pada penelitian ini kami mengucapkan terimakasih kepada Poktan Kopi Manglayang telah memberikan bantuan berupa penggunaan alat dan masukannya selama penelitian ini dilakukan.

\section{DAFTAR PUSTAKA}

Anggara, A., \& Marini, S. (2011). Kopi si Hitam Menguntungkan Budi Daya dan Pemasaran. Yogyakarta: Cahaya Atma Pustaka.

BSN. (2004). Kopi Bubuk SNI 3542-2004. Jakarta: Badan Standardisasi Nasional.

Ciptadi, W., \& Nasution, M. Z. (1985). Pengolahan Kopi. Bogor: Agro Industri Press.

Erowid. (2014). Caffeine Effect. Diambil 12 September 2020, dari

http://www.erowid.org/chemicals/caffeine/caffeine. htlm

Farhaty, N., \& Muchtaridi. (2016). Tinjauan Kimia dan Aspek Farmakologi Senyawa Asam Klorogenat pada Biji Kopi: Review. Farmaka, 14(1), 214-227.

Farida, A., Ristanti, E., \& Kumoro. (2013). Penurunan Kadar Kafein dan Asam Total pada Biji Kopi Robusta Menggunakan Teknologi Fermentasi Anaerob Fakultatif dengan Mikroba Nopkor MZ-15. Jurnal Teknologi Kimia dan Industri, 2(3), 70-75.

Hawa, L. C., Sumardi, H. S., \& Elfira, P. S. (2009). Penentuan Karakteristik Pengeringan Lapisan Tipis Ikan Kembung (Rastrelliger sp.). Jurnal Teknologi Pertanian, 10(3), 153-161.

Israyanti. (2021). Perbandingan Karakteristik Kimia Kopi Luwak dan Kopi Biasa dari Jenis Kopi Arabika (Caffea arabica L.) dan Kopi Robusta (Caffea canephora L.). Universitas Hasanuddin.

Kirchheimer, S., \& Smith, M. W. (2004). Coffee: The New Health Food? Diambil 29 Juni 2020, dari http://www.howstuffworks.com/framed.htm?parent=ca ffeine.htm\&url=http://men.webmd.com/features/coffee -new-health-food

Kristiyanto, D., Pranoto, B. D. H., \& Abdullah. (2013). Penurunan Kadar Kafein Kopi Arabika dengan Proses Fermentasi Menggunakan Nopkor MZ-15. Jurnal Teknologi Kimia, 2(4), 170-176.

Liska, K. (2004). Drugs and The Body with Implication for Society (7 ed.). New Jersey: Pearson.

Mulato, S., Widyotomo, Misnawi, Sanali, \& Suharyanto, E. (2004). Petunjuk Teknis Pengolahan Produk Primer dan Sekunder Kakao. Bogor: Bagian Proyek Penelitian dan Pengembangan Kopi dan Kakao.

Nazar, P. A., Rejo, A., \& Hayati, A. (2016). Dekafeinisasi Biji Kopi Luwak (Civet Coffee) dengan Menggunakan Ekstrak Buah Nanas (Ananas Comosus (L) Merr) dan Buah Pepaya (Carica Papaya). Universitas Sriwijaya.

Nuryati, N., Budiantoro, T., \& Inayati, A. S. (2018). Pembuatan Enzim Papain Kasar dari Biji, Daun dan Kulit Pepaya dan Aplikasinya untuk Pembuatan Virgin Coconut Oil (VCO). Jurnal Teknologi Agro-Industri, 5(2), 77-89.

Oktadina, F. D., Bambang, D. A., \& Bagus, H. A. (2013). Pemanfaatan Nanas (Ananas Comosus L.Merr) untuk Penurunan Kadar Kafein dan Perbaikan Citarasa Kopi (Coffea Sp) dalam Pembuatan Kopi Bubuk. Universitas Brawijaya.

Petracco, M. (2005). Prcolation Espresso Coffee: The Science of Quality. SCA: Elsevier Academic Press.

Putri, A. M. J., \& Komang, A. N. (2017). Pengaruh Penggunaan Getah Pepaya (Carica Papaya L) pada Proses Dekafeinasi terhadap Penurunan Kadar Kafein Kopi Robusta. Universitas Udayana.

Rahardjo, P. (2012). Panduan Budidaya dan Pengolahan Kopi Arabika dan Robusta. Jakarta: Penebar 
Swadaya.

Ramalakshmi, K., Kubra, I. R., \& Rao, L. J. M. (2008). Antioxidant Potential of Low-Grade Coffee Beans. Food Research International, 41, 96-103.

Rejo, A., Rahayu, S., \& Panggabean, T. (2010). Karakteristik Mutu Biji Kopi pada Proses Dekafeinasi. Universitas Sriwijaya.

Wijaya, D. A., \& Yuwono, S. S. (2015). Pengaruh Lama Pengukusan dan Konsentrasi Etil Asetat terhadap Karakteristik Kopi pada Proses Dekafeinasi Kopi Robusta. Jurnal Pangan dan Agroindustri, 3(4), 15601566.

Winarno, F. G. (2004). Kimia Pangan dan Gizi. Jakarta: Gramedia Pustaka Utama.

Yatim, W. (2003). Biologi Modern Biologi Sel. Bandung: Tarsito.

Yusianto, I., Saryono, C. A., Nugroho, D., \& Marwadi, S. (2012). Characterization of Animal Preference to Arabica Coffee Varieties and Cup Taste Profile on Domesticated "Luwak" (Paradoxorus hermaphroditus). Procidings of 24th ASIC International Conference on Coffee Science (pp.136-144). San Jose, Costa Rica, 136-144. 